\title{
The Conception and Practice of Research-Based Teaching in Research Universities
}

\author{
Xiaoyan Zhang* \\ School of Life Sciences and Technology, Tongji University, \\ Shanghai, China \\ xyzhang@tongji.edu.cn \\ *Corresponding author
}

\begin{abstract}
Scientific research and instruction are the two fundamental activities carried out by university faculty. Science is like the source of a river and teaching is like its flow. Teaching without the support of scientific research will lose its soul. Instructors who are engaged in scientific research have a deeper understanding of what they are going to impart. They can extract more useful knowledge, views and theories for students to learn. The combination of scientific research and teaching will benefit the training of innovative scholars. Implementation of researchbased teaching reform based on the principle of "driving teaching by scientific research, deepening scientific research by teaching" will help develop a complementary system of teaching and scientific research in the teaching practice of bioinformatics courses. The results show that students acquired new knowledge more effectively in courses that incorporatedactive, inquiry-based, and collaborativelearning, assisted with information technology, in comparison with traditional courses.
\end{abstract}

Keywords-research university; research-based teaching; bioinformatics; integrating scientific research and teaching

\section{INTRODUCTION}

Research universities are important training base for creative and high-quality professionals; it is also a major player in development of science, technology and culture as well as an innovative workforce for the nation. Thefunctions of universities within the scientific research system are not only conducting basic research of importance for the nation but also carrying out applied studies and projects as well as developing innovative and professional talents across all fields. They should strive for living up to the expectations of the nation, society, and public and carry out the historical mission that the society entrusts them with. A university should be the central place where teaching and research depend on and support each other.

\section{A. Instrinsic Features of Teaching and Research at Research Universities}

Teaching and research are highly correlated and supportive of each other, which is one of the most significant and important characteristics of research universities. Organizational characteristics of research universities require that they must continue to improve the integration mechanism of their teaching and research activities, and balance the production of innovative talents and research output. The intrinsic characteristics of teaching and research activities at research institutions determine that the emphasis cannot be one-sided on

\author{
Peng Nan \\ School of Life Science, Fudan University, Shanghai, China \\ nanpeng@fudan.edu.cn
}

teaching or research, but should adhere to the harmonious development of both. It is only through focusing on both teaching and research that research universities may achieve harmonious and sustainable development.

Furthermore, the constant update of knowledge and information in one's professional field urges faculty to conduct scientific research, which can promote the improvement of teaching through increasing the depth and broadening the scope of theoretical knowledge. We all know that the purpose of scientific research is to explore the unknown in our professional fields and to develop innovative approach to achieving that. With the rapid updates of knowledge in modern times, constant emergence ofadvanced theories, highly frequent collaboration and minute classification across many disciplines, major adjustments and course reforms from time to time, faculty needto keep themselves abreast of the development of the field, try teaching new courses, acquire new knowledge, and understand theories of related subjects and learn how to apply new pedagogies in their teaching practice.

\section{B. Chinese Research University Standards}

In recent years, there is a growing body of literature about China's academic research universities. To define research universities, all of the institutions of higher education in China are ranked based on their scientific research output scores (in descending order). An institution is called a research university is defined if the total score exceeds $61.8 \%$ of the national average score of scientific research output. These research universities are further classified into Type I and TypeII research universities. The classification criteriaare: Type I universities are the top 10 ranked universities based on their scientific research output; or those institutions that provide a superior innovative research environment for graduate students than the average research institution nationally and award more than $100 \mathrm{Ph}$.D.s each year. Type I institutions are those that don't meet the criteria for Type I. Research universities in China should strive for a unique educational philosophy, high-quality faculty who are capable of knowledge creation, innovation and transformation, and training a large number of high-quality innovative talents[1]. 


\section{The Conflict of Teaching and Research atResearch Universities}

The distinction between teaching and research are accompanied by the emergence of research universities. Since then, "publish or perish" gradually become the key principle that faculty at research universities follow. However, there are some real conflicts between teaching and research activities.

It seems that the contradiction between research and teaching in time and space has plagued teachers for a long time, which is also a realistic and urgent problem facing teaching reform and higher education. In spite of this, introduction of new instructional methods has been slow and difficult across all the science disciplines, forsimilar reasons. In the current culture of academic biology, particularly at large researchuniversities, efforts to improve faculty teaching effectiveness are generally neither encouraged nor highly valued [2].In research universities, the goals of research-based teaching are to change the learning style of students, to encourage them to take initiative, and to develop their enthusiasm and creativity, which require the instructor to adapt their instructional strategies and explore innovative pedagogical approaches. The role of faculty should be transitioned from knowledge transmitter and instiller to organizer, guider and promoter for students while they're acquiring knowledge. Based on understanding ofthe relationship between teaching and research functions and strategies to strike a reasonable balance between research and teaching in a bioinformatics course, this study intends to explore the integration of teaching and research and provide some theoretical references for related research.

\section{Practice Of Research-BASEd TeAching}

\section{A. The Significance of Research-Based Learning in Research Universities}

The combination of teaching and research is a key feature of teaching processat research universities, which is also a guiding principle for undergraduate education and development of students'research capacity.

As indicated in "Understanding and Practice of Researchbased University Teaching Mode" by HuiWang et al from Tsinghua University, the connotation of research-based teaching is combination of teaching and research, talent training and discipline construction. Wang thinks that teaching process is a communication process between teachers and students and should provide relatively relaxed and open atmosphere with a combination of teaching and research for students to study and explore their personality and intellectual pursuits [3]. However, the present system of education in China rarely gives young people a chance to assess their potential abilities as future scientists. In particular, very few students are exposed to science curricula that allow them to explore the world in the way that working scientists do. Instead, science education in the China-from elementary school through university-usually focuses on helping students absorb what scientists have already discovered about the world.

Research-based teaching, with focus on the forming and development process of the discipline and teacher-student interaction as the main feature, guides students to learn scientist's thinking approach to analyzing and exploring unknown phenomena. Therefore, the purpose of classroom teaching is to stimulate students' interest in learning and exploring and to guide students to independently explore and experience the occurrence process of knowledge, and help them pursue the essence of scientific thinking activities. Thus, students are educated to be able to treat scientific knowledge with their own thoughts and opinions, instead of accepting knowledge passively. Essentially, research-based study means learning with scientific approaches, whose methods are diverse according to specific circumstance of different institutions. If the faculty member can use his or her own research as examples or referencesto illustrate the concept, the researchbased study will be more efficient. The research-based teaching is a new teaching concept and philosophy under the requirements of social development and universities'selfdevelopment, whose purpose is to achieve the goal of selfdevelopment through incorporating students into the teaching process [4].

- Firstly, the content of this course should be the latest research achievements. The teacher should also use the existing rich academic resources and keep track of academic focus points, and introduce concept of scientific research into undergraduate teaching to cultivate and improve students' comprehensive quality of innovation, thinking, analyze, writing and literature review, train students to "find problems, analyzeproblems and solve problems" and provoke the inner power of students so that they can learn with persistent self-discipline through diverse trainings. Meanwhile, scientific research is an activity that requires lots of practice.

- Secondly, research-based teaching combines teaching contents with scientific works. Teaching in research areas that faculty specialize in will be helpful to avoid the stiff teaching mode of repeating what the book says and activate the class. With the rapid development of society, science and technology, knowledge updates occur more frequently. As one of the main sources of students' knowledge, contents of textbooks couldn't update in time to reflect the field's latest development. This requires that faculty introduce the newest scientific achievements into teaching process actively, selectively, timely and effectively to keep teaching contents' pioneering characteristic and the sense of times, thereby enhancing the scientific research vitality of teaching, broadening the thoughts of students, and promoting their creativity.

- Thirdly, developing research capability in the information age is the basic requirement of a scholar. In the information age, the standard measure of talent lies in if they have access to, be able to screen, analyze and process complex information, if they are able to quickly adapt to diverse and changing environment, if they have the ability to solve complex problems.Based on the history of science and technology development, once a significant breakthrough is made in some particular field, it usually brings about great changes in lifestyle, 
learning style and the mode of production. The development of science and technology has its own laws, and we expect that such changes will lead to significant challenges in higher education. Now that we have witnessed the trends, our colleges and universities should take forward-looking measures in the standard of cultivating talents and the design of curriculum system and students' overall knowledge structure to tackle the challenges of the future

\section{B. Teaching practice of bioinformatics course}

Introduction to Bioinformatics is an interdisciplinary course, which is characterized by wide horizon of knowledge and fast update rate. With the pace of scientific discovery continuing to accelerate, the scientific and technological advances in this century will almost certainly exceed those of the past 100 years. The spread of science - and of scientific judgments about the effects of current actions on the future - to every nation is urgently needed to create a more prosperous and rational world. But already there are clear signs that our societies are illprepared for what science brings[5].

According to the study of Smerden, an academician from the American Academy of Engineering, the half-life of contemporary knowledge is about 2.5 to 7.5 years. If we only teach students knowledge instead of how to obtain it, their knowledge will be out of date soon and the cultivation of students will be ineffective. Only if students master the ability of learning knowledge independently shall they apply knowledge learned from the courses to their future study and work. Constantly discovering new problems in practice is the fundamental driving force of students' learning and their enthusiasm will not fade if the force is inexhaustible. As science and technology advance, the amount of information is growing exponentially and the cycle of knowledge update and achievements transformation is shortening continuously. The talent cultivation of universities is no longer one-off and terminative. How to follow the concept of lifelong education, establish target and standard of talents training scientifically, construct diversified systems and modes of personnel cultivation, reform the curriculum system, teaching material and methods, strengthen ability development of students and improve their adaptability and competitiveness has set out great challenges to the talent cultivation in universities[3].

At the beginning of the course, we encourage students to combine biology and information science from interdisciplinary and innovative perspective to seek a breakthrough point of a scientific issue, to become a pioneer frontier and high-tech talent. Each student focuses on the current international biomedical research topics, combined with his or her interest in scientific issues. Based on this, the students may choose a scientific question as a starting point, and keep track of the course of progress on this issue. We encourage students to have a good understanding of the basic concepts of the premise through self-learning, self- study method to get ideas and methods to solve problems. Learned in the classroom in a timely manner the basics applied to solve real problems go. However, as the course progressed, different knowledge fragments were linked into a knowledge chain or a complete solution that allows students to not only master the knowledge points, but also develop deep understanding of the field. Naturally they are able to integrate several knowledge modules organically and develop a systematic understanding of bioinformatics.

Database query is one of the most important chapters of this course. When teaching Bioinformatics course to the professional students of medical school, we considered characteristics of these studentsand focused on teaching all kinds of disease-related mutation databases. During the progress of the course, it was of great importance to guide the students to discover problems. As international research moves on, the number of databases increases rapidly. Students were required to think about the necessity of developing the database. They may consider whether a big and comprehensive database is better than a small but detailed one. Next, a heated discussion will be held about this question. At last students would be led to try to solve these problems with methods of bioinformatics. After finishing all these steps above, students were very interested in such research-based learning methods and suggested a variety of solutions proactively. Students generally believed that the problems they had to solve were very challenging. Only then did they have the chance to discover what science really is and to recognize their aptitude for it. Each report of these students is distinct from each other and the methods they selected to solve those problems vary as well. The discussion of this course also inspired us to complete a disease-related database search engine two years later, which was published in a high level international academic journal [6]

Through the study of the whole semester, students' enthusiasm of active learning and ability of solving problems have increased a lot. Some students even have achieved higher level of active learning than expected and some reports of them contribute to our research work, which has been publishedon international journal[7].

\section{THE INTERACTION BETWEEN TEACHING AND RESEARCH IN RESEARCH UNIVERSITY}

Scientific research has an enormous impact on the academic fame of research-based university and is the driving force of its continuous progress and fast growth. While teaching, as the most basic approach of talent training also influences greatly the existence and development of research-based university. Hence, scientific research and teaching play the same important role in the construction of research-based university and both of them are indispensible and the atonements mutually.

Firstly, research-based university has abundant advantages, such as advanced scientific research direction, sufficient scientific research funds, abundant scientific research achievements, dense academic atmosphere and so on. All of these benefit both undergraduate teaching and teacher's scientific research a lot. On one hand, teachers could integrate their research into teaching and deliver the newest research achievement to the undergraduates. On another, the undergraduate students could improve their abilities of identifying, analyzing and solving problems through participating in scientific research. What's more, teachers also could carry out individuation teaching method and improve their abilities of management and research organization. Thus, research-based university not only should encourage policies of 
laying equal stress on scientific research and teaching, but also have to create measures to integrate them.

Secondly, research-based universities are the representatives of colleges and universities with high academic level in our country and our society has strict requirements and eager desires for its training of qualified undergraduates. Meanwhile, what differ research-based universities with normal colleges is 'research'. So, scientific research is their core competitiveness. A harmony relationship between teaching and scientific should be established. Research-based university not only should pay more attention to teaching, but also should advocate the closely integration of scientific research and teaching.

Third, it doesn't mean that only teachers who have done a good job in research can undertake research-based teaching, all teachers can. It should become a basic teaching method of university teachers and all of teachers should take researchbased teaching. Teachers are the key to research-based teaching. Their positive and active practice determines whether researchbased can be carried out, what extent can be achieved and what kind of effect can be received.

\section{TEACHERS' GUIDING ROLE}

The core factor of research-based teaching is problem. The design, extracting, summarization, expression and form of problem are critical to research-based teaching.Our goal as teachers shouldbe to exposeour students to the discovery process and to excite them about challenges at the frontiers of knowledge. We should be to enable students to appreciate and participate in science as a special way of knowing about the world.

Firstly, teachers have to stand in the forefront of the discipline and be able to take their students to the academic forefront. They can digest the latest theories of this discipline and practical issues, constantly identify new problems in the forefront of the subject, and maintain altitudinal sensibility and niche targeting topic selection to the academic research field of this discipline. In research-based teaching teachers also have design appropriate problems to organize students to learn and research independently on these problems.

Secondly, Teachers should interact with students actively, develop together, rightly treat the relationship between teaching knowledge and cultivating ability, pay more attention to the cultivation of students' independence and self-support, lead them to doubt, research and study in practice, promote students to learn with initiative and individual character under the guideline of teachers. Teachers should arouse students' learning interest through teaching process. Students are not limited to textbooks and what teachers say in class. Meanwhile, they will try to enrich knowledge actively and explore freely.

Thirdly, Teachers should motivate students' initiative and enthusiasm of study and lead them to think deeply so that they can internalize external knowledge to their own knowledge, ability and comprehensive quality. Teachers also should respect students' personality, pay attention to individual difference, satisfy various needs of student, construct appropriateeducation atmosphere that involves all students in, arouse their enthusiasm of learning, train their attitude and ability of learning and applying knowledge, and promote the development of each student.

\section{CONCLUSIONS}

The combination of teaching and scientific research is the basic way to cultivate talents with high quality and produce high-level results of scientific research, and also is the driving force to promote the development of this discipline. Scientific research should become part of teachers' life, through which teachers can well know the newest trends of the subject and excavate new teaching resources. Thus, forefront information of the subject will be imported into the class and applied to teaching by teachers and explained to students in a simple way, inspiring their innovative spirits, expanding ideas of students, and deepening the teaching contents.

Meanwhile, teaching not only raises problems for scientific research, but also provides ideas and directions to solve them. Teaching is not simple repetition, and it can promote reflection. Teachers reflect themselves in teaching process, which happened to be necessary for more high-level scientific research. Teaching practice promote teachers to comprehensively understand the basic theoretical knowledge, to research and experience from different perspectives and totally new points of view. New ideas and explanations will be introduced into research and the research foundation of teachers will be strengthened at the same time.

\section{ACKNOWLEDGMENT}

This work was supported by the 2010 Shanghai Englishdemonstration courses funded (Shanghai Education Commission high 2010-42), 2009-2012 Tongji University "the bioinformatics team building" and" bioinformatics Quality Course Construction Project", The fourth installment colleges Specialty Construction funded 2009 (TS1Z231).

\section{REFERENCES}

[1] "Chinese University Evaluation" discussion group: Classification of scholars have proposed new standards for Chinese universities - China 133 research study teaching university list

[2] B. Wood, M.Gentile, "Teaching in a research context" [J]. Science, 2003, 302(5650): 1510.

[3] H.Wang, W.Zhang, and D.Yuan, "Some Ideas and Practics on the Teachering Model in Research University,"Research On Education Tsinghua University, 2002,23(1). 17-22

[4] R.Vale, J. DeRisi, R. Phillips, et al., "Interdisciplinary Graduate Training in Teaching Labs," Science, 2012, 338: 1542-1543

[5] B.Alberts, “A wakeup call for science faculty”[J]. Cell, 2005, 123(5): 739-741.

[6] Z. Li, X. Liu, J. Wen, et al. "DRUMS: a human disease related unique gene mutation search engine," [J]. Human Mutation, 2011, 32(10): E2259-E2265.

[7] L. Marcelo, "I do not make a distinction between teaching and research," [J].Science, 2007, vol 317,pp. 70-71

[8] X. Zhao, Q Liu, X. Zhang*2012, Dr.VIS: a database of human diseaserelated viral integration sites, Nucleic Acids Research, 2012, Vol. 40, Database issue D1041-D1046 